\title{
MATHEMATICAL MODEL OF GEODINAMIC RISK ASSESSMENT
}

\author{
V.N.Burkov1, vlab17@bk.ru, \\ I.V. Burkova, ${ }^{1,}$, irbur27@mail.ru, \\ V.A.Minaev³,m1va@yandex.ru, \\ A.O. Faddeev ${ }^{4}$, fao1@mail.ru \\ ${ }^{1}$ V.A. Trapeznikov Institute of Control Sciences of Russian Academy of Sciences, \\ Moscow, Russian Federation, \\ ${ }^{2}$ Russian State University for the Humanities, Moscow, Russian Federation, \\ ${ }^{3}$ Bauman Moscow State Technical University, Moscow, Russian Federation, \\ ${ }^{4}$ The Academy of Law Management of the Federal Penal Service of Russia, \\ Ryazan, Russian Federation
}

\begin{abstract}
A mathematical model of geodynamic disasters assessment, specifically earthquakes, based on an analysis of geodynamic instability indirect indicators, namely, horizontal gradients of gravity anomalies in isostatic reduction, is presented in this paper. Special attention is paid to the probability mathematical model of assessment of seismic risks, the core of which is the representation of probable geodynamic states of geologic environment as a simplest event flow, followed by the construction of the Kolmogorov differential equations system. The principal results of the practical application of the mathematical models developed by the authors to assess seismic risks exemplified by way of the examples of the Baikal region and the north-western territory in Turkey are given and considered herein.

Keywords: mathematical modeling, geodynamic risk, gravity anomalies, geodynamic hazards, stresses and displacements, geologic environment, earthquakes.
\end{abstract}

\section{Introduction}

The events occurred in Japan in March last year have clearly demonstrated the extreme vulnerability both of the population and the territory to the realized hazardous natural processes of geodynamic origin, to be more specific, to the climax of the high-energy seismic events, i.e., the earthquakes. Therefore, the problems how to protect the population and the territories from dramatic effects of hazardous natural and technogenic processes are at present time acute and critical practically for every country or state, no matter what the location on the Earth.

It is evident that these problems cannot be solved if data on spatial distribution of such processes, intensity of their effects and periodicity of their occurrence are not available. Conventionally, for this purpose used are technologies of evaluation of dynamics of hazardous geodynamic processes on the basis of the known statistics data. But what should be done if no statistics data are available, or if they are not sufficient? Or if it is required to assess the probability of seismic event realization for some specific "point" objects?

In order to provide an efficient assessment of the geodynamic risks, an adequate high-quality monitoring of the geologic environment in these areas is required, which should be targeted to an estimation of the dynamics of the hazardous geodynamic processes. Such monitoring is currently based either on the methods of the conventional qualitative description or the performance of instrumentation investigations to trace the realization of the hazardous geodynamic events under real-time conditions. But both of these approaches are not capable of supplying sufficient data enabling to take adequate preventive measures within the high-risk territories.

In such a case, it is necessary to develop and use some modern mathematical models which should provide for the proper assessment of the geodynamic risk areas in preventive manner. An entirely adequate single approach and a new technology, based on mathematical methods, enabling us to solve the formulated problem of the seismic risk estimation both in orogenic areas and platform territories are called for.

We succeeded in solving some individual issues of this problem previously [1-8]. So, among other things, the assessments of the geodynamic risks for the central part of the Eastern-European platform as 


\section{Информатика и вычислительная техника}

well as for a number of strategic, industrial and most critical objects [5-8] have been carried out by us [1-3].

Our papers mentioned above contain both the mathematical models and the results of mathematical modeling of the stressed-and-strained state of the geologic environment, on the basis of which the appropriate geodynamic risk assessments for the territorial objects, varying in their length, have been completed by us.

In contrast to the conventional techniques, resting on application of statistics data only, the offered mathematical models let us create plausible assessment \& forecasting maps of equipotential distribution of geodynamic risk index numbers for different territories, that is supported in the papers by the relevant test calculations and correlations between the results obtained in the calculations and the distributions of the hazardous geodynamic events actually occurred in various regions in Russia as well in a number of other countries.

Let us consider what our seismic risk assessment technology represents which special features it shows and what results may be achieved in applying our technology in practice.

\section{Methods of Construction of Mathematical Models for Seismic Risk Assessment}

The unique mathematical technology of an assessment of sites of probable occurrence of geodynamic disasters, in particular, the earthquakes, developed from the outcomes of the long-time researches by scientists from Russian New University (Moscow), rests on a numerical analysis of spatial distribution of geodynamic anomalies [9]. In other words, based on the analysis of indirect indicators of the geodynamic instability, i.e., the horizontal gradients of the gravity anomalies in the isostatic reduction, a mathematical model of the geologic environment of the studied territory is constructed, and, upon the results of the mathematical modeling, the fields of the tectonic strains and the displacements in the geologic environment for any depth level are reconstructed.

To illustrate this, let us depart from the real geologic environment and imagine a homogenous isotropic elastic space of closed form, which takes the form of a parallelepiped, representing a certain "plate" with the known averaged values of its density, shear modulus and Young modulus (or Lamé constants). Let us also assume that we consider this environment ("the plate") in terms of the Newton's law rheology, and that a distributed load or a distributed external force is applied to this "plate" that acts strictly vertically from bottom upwards. Due to such action, the structurally inhomogeneous stress and displacement fields appear in this isotropic environment (in "the plate") (Fig. 1).

In this case, the distributed external force is $P(x, y)$, the known discrete values of which are given with a certain fixed pitch along axes $X$ and $Y$, are represented as a row (1), i.e., the anomaly gravity field is decomposed in the isostatic reduction into its constituent zonal harmonics as follows:

$$
P(x, y)=\frac{p_{00}}{4}+\frac{1}{2} \sum_{m=1}^{s} p_{m 0}+\frac{1}{2} \sum_{n=1}^{l} p_{0 n}+\sum_{m=1}^{s} \sum_{n=1}^{l} p_{m n},
$$

where, for example,

$$
p_{m n}=a_{m n} \cos k_{x} x \cos k_{y} y+b_{m n} \sin k_{x} x \cos k_{y} y+c_{m n} \cos k_{x} x \sin k_{y} y+d_{m n} \sin k_{x} x \sin k_{y} y ;
$$

$a_{m n}=\frac{4}{a b} \int_{0}^{a} \int_{0}^{b} p(x, y) \cos k_{x} x \cos k_{y} y d x d y ; k_{x}=\frac{\pi m}{a} ; k_{y}=\frac{\pi n}{b} ; a, b-$ the length, $(X)$ and the width $(Y)$ of

the territory being considered, respectively; $p(x, y)$ - the values of isostatic anomalies of the gravity field (Fig. 2).

Then, the components of the stress tensor and those of the displacement vector in the geoenvironment should be represented in a similar way, e.g., for the normal components of the stress tensor they are represented by the ratios of kind (2) as follows:

$$
\sigma_{\alpha}(x, y, z)=\frac{1}{4} \sigma_{\alpha}^{(00)}+\frac{1}{2} \sum_{m=1}^{s} \sigma_{\alpha}^{(m 0)}+\frac{1}{2} \sum_{n=1}^{l} \sigma_{\alpha}^{(0 n)}+\sum_{m=1}^{s} \sum_{n=1}^{l} \sigma_{\alpha}^{(m n)}
$$

where $\alpha \in\{x, y, z$,$\} .$

The proposed approach is cost-saving since no instrumentation surveys are required.

The mathematical model can be further improved (or refined) provided that the spatial distributions of the density value and the values of the Lamé constants within the geo-environment volume are known (so-called Model of Type III). 


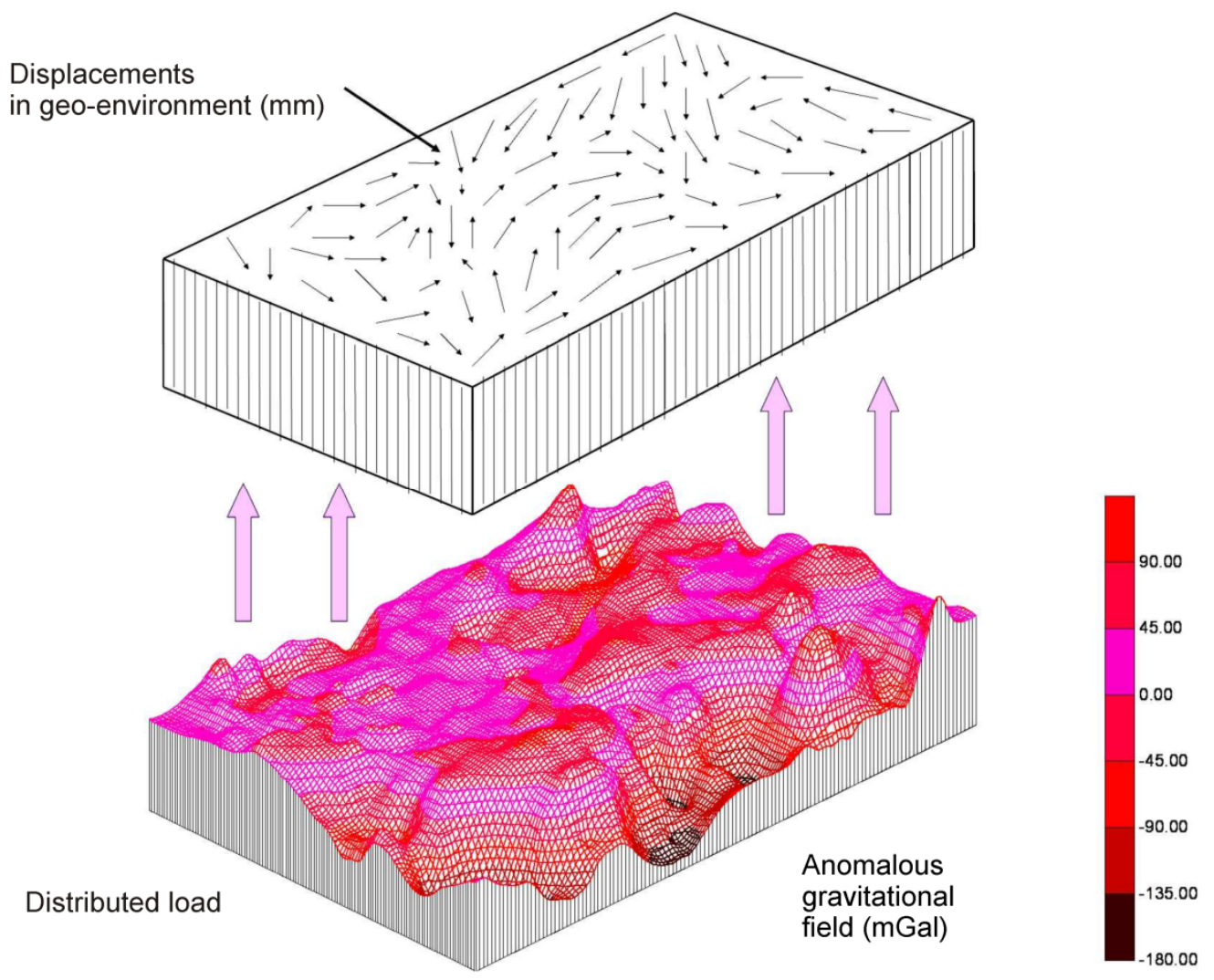

Fig. 1. Model of generation of stresses and displacements in elastic geo-environment volume
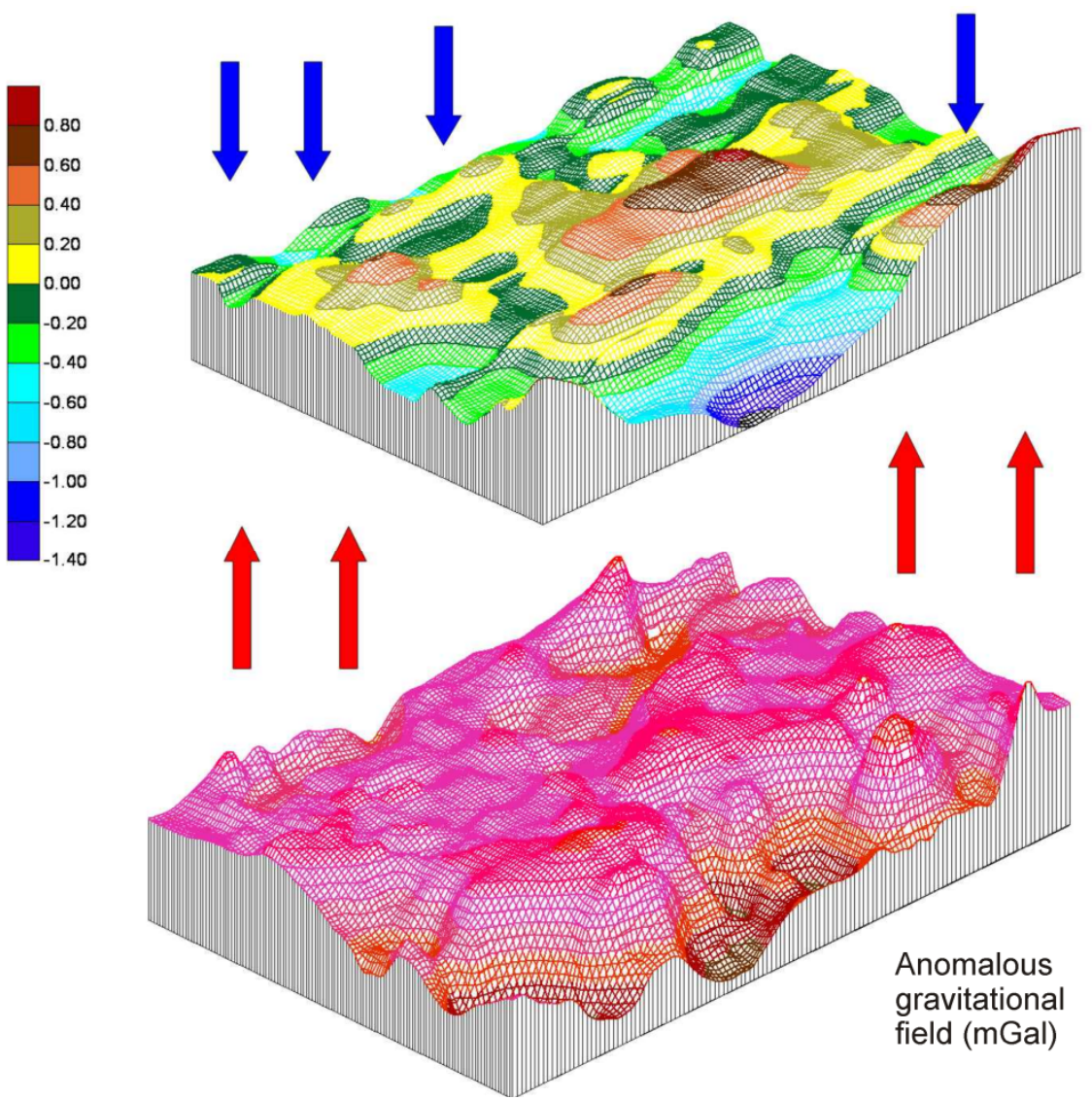

Modern

vertical

movements

(mm/year)

Fig. 2. Another model of generation of stresses and displacement in geo-environment (Type II Model) 


\section{Информатика и вычислительная техника}

Finally, the most credible model should be the Model of Type IV, in which the Maxwell rheology of the environment is treated. This model is of particular value for predicting purposes, since it makes possible to take into account the seismic strain energy dissipation.

All above models have one important property in common only: they are capable of producing a qualitative evaluation of the tensor stress and the displacement vector components in the geologic environment at the deterministic level. The subsequent mathematical processing of the obtained fields of stresses and displacements makes possible to quantify such important characteristics of the geologic environment, which are critical for the seismic hazard assessment, like the relative density of the potential energy of the strained rock in the geo-environment, the vertical and horizontal displacements occurring in the geologic environment, the gradients of these displacements, that is added by mapping to show assessing of the equipotential distribution of index numbers of hazards of geodynamic origin [10].

The data on territorial distribution of the said characteristics permit to proceed with the construction of a probability mathematical model to assess geodynamic risks, which is labeled by us as the Model of Type V. This model is based on representation of the probable geodynamic states of the geologic environment as a simplest event flow, followed by the construction of the system of the Kolmogorov differential equations to estimate the probability of finding the geo-environment in the above states [11].

Let us explain the essence of this model (Fig. 3). Assume that at the given time $t_{0}$ the volume of the geo-environment has a certain energy parameter of exogenic geological processes (EGP) $\mathrm{E}_{0}$, which is a quantifiable characteristics of the energy of the processes in progress in the geo-environment volume.

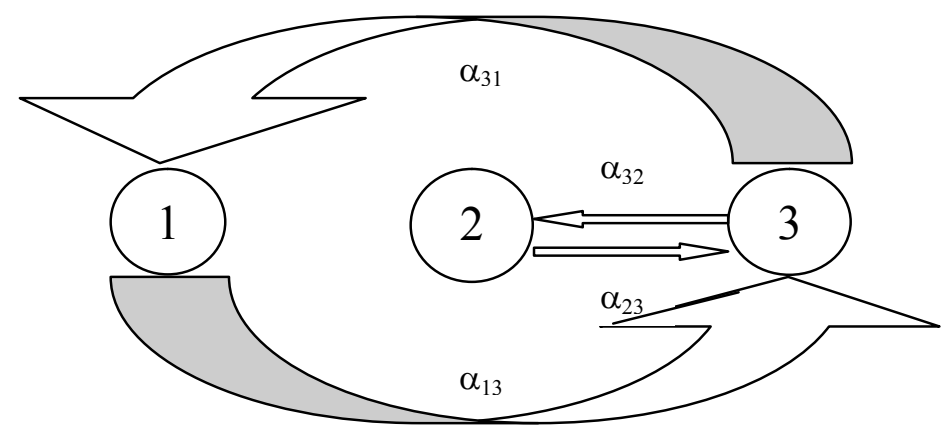

Fig. 3. Scheme of reciprocal transitions of the model volume of the geo-environment by states 1, 2 and 3

In doing so, let us designate as state 1 such a state of the volume of the geo-environment, when $\Delta E_{1}=E_{1}-E_{0} \rightarrow 0$, i.e., when the volume of the geo-environment is in its stable equilibrium state $\left(E_{1}\right.$ is an EGP energy potential in the volume of the geo-environment at the time $t_{1}$ ).

State 2 should be defined as a state of the geo-environment volume, when the geo-environment is in the state of its unstable non-equilibrium, i.e., $\Delta E_{2}=E_{2}-E_{1}>0\left(E_{2}\right.$ is an EGP energy parameter in the volume of the geo-environment at the time $t_{2}$ ).

State 3 should be a quasi-equilibrium state of the geo-environment volume, when $\Delta E_{3}=E_{3}-E_{1}>0$, with $\Delta E_{1}<\Delta E_{3}<<\Delta E_{2}$ ( $E_{3}$ is an EGP energy parameter in the volume of the geo-environment at the time $t_{3}$ ).

Thereafter, the changes in the above mentioned probabilities should be defined by the following system of the Kolmogorov differential equations (3):

$$
\left\{\begin{array}{l}
p_{1}^{\prime}(t)=-\alpha_{13} p_{1}(t)+\alpha_{31} p_{3}(t), \\
p_{2}^{\prime}(t)=-\alpha_{23} p_{2}(t)+\alpha_{32} p_{3}(t), \\
p_{3}^{\prime}(t)=\alpha_{13} p_{1}(t)+\alpha_{23} p_{2}(t)-\left(\alpha_{31}+\alpha_{32}\right) p_{3}(t), \\
p_{1}(t)+p_{2}(t)+p_{3}(t)=1 .
\end{array}\right.
$$

In setting up the system of the equations for probabilities $p_{1}(t), p_{2}(t)$ and $p_{3}(t)$ of finding the environment in states 1,2 and 3, of great importance is the calculation of the numerical values of the intensities of the processes $\alpha_{i j}$, representing physically a sum of the energy parameters of the processes in progress in the system, the completion of which lead to an immediate transition of the system from its state 
$i$ to the state $j$. The process intensities of the processes $\alpha_{i j}$ are evaluated on the basis of the data on the strain values, the vertical and horizontal displacements in the geo-environment as well as their gradients obtained from the respective mathematical modeling.

The models described herein have been successfully applied by us to the seismic risk assessments for the Baikal region, the north-western territory in Turkey, and, first of all, to the Istanbul environs. Let us present our principal results obtained therein.

\section{Results of Mathematical Modeling}

The similar model has been originally applied to the seismic risk assessment for the Baikal region territory [12]. The map of the equipotential distribution of the complex geodynamic risk index numbers, indicating in our case the probability of occurrence of a seismic event, that is constructed on the basis of the computations and that depicts the plotted epicenters of the earthquakes, which actually took place one year later upon the computation, has demonstrated the efficiency and the adequacy of our model: the epicenters of the actual earthquakes are found on the map just at those sites which were derived from our model as most hazardous with respect to their geodynamics (Fig. 4).

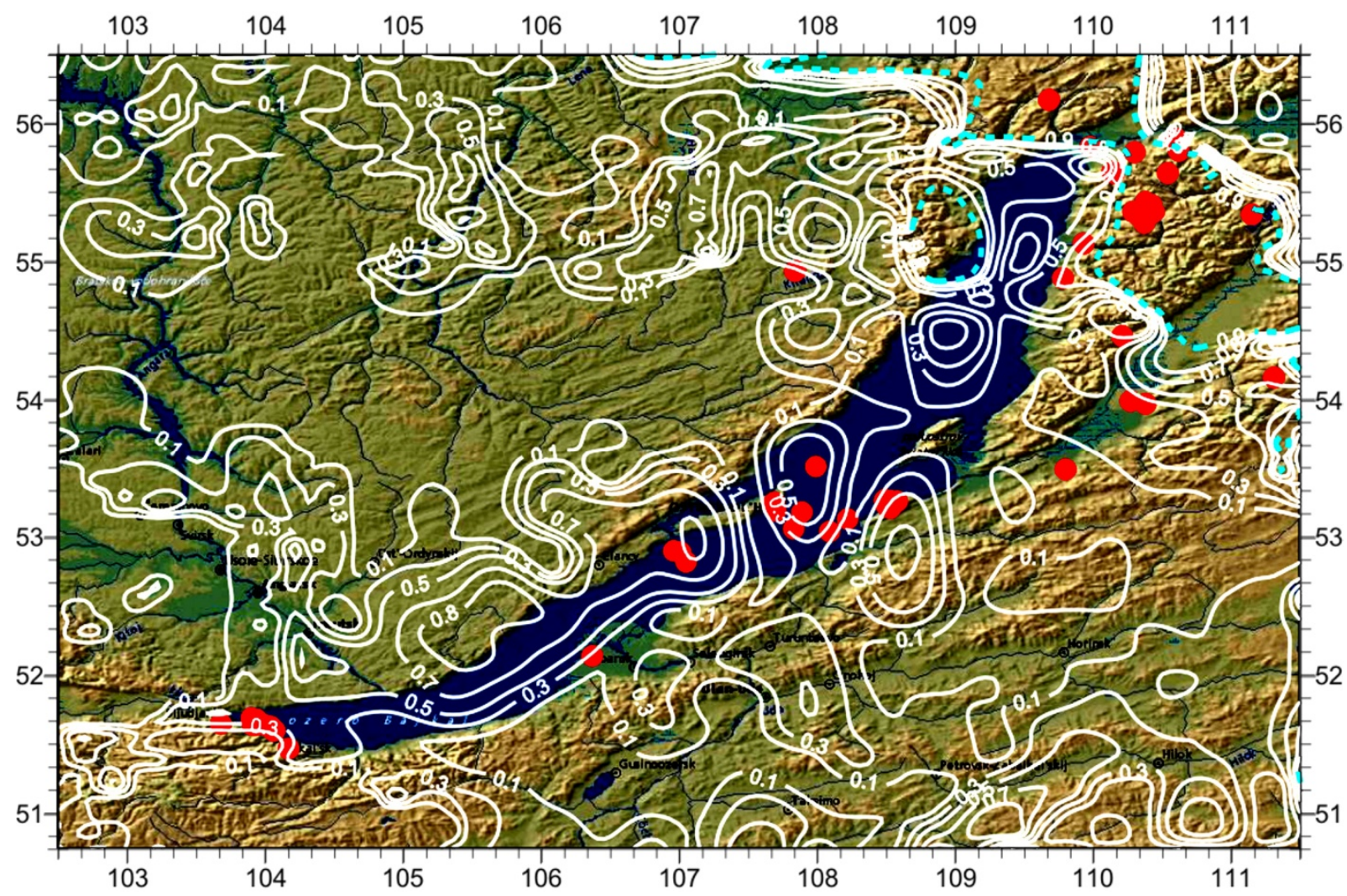

Fig. 4. The map of equipotential distribution of complex geodynamic risk index numbers for the Baikal region territory (The light-blue dotted line shows the areas with a probability of the occurrence of seismic events up to 0,9 )

It is significant that such maps reflect not an integral probability of a seismic risk for the region as a whole, but they indicate the "point-area" probability of the occurrence of the seismic events. Sizes of such "point-areas" depend on a linear length of the territory being considered so that their sizes may be within the range from several square kilometers actually up to several hundred square meters.

Let us dwell in more detail on the results of our research in the assessment of the seismic risks for the Turkish territory in the vicinity of Istanbul.

Earthquakes of magnitude 7 to 7,5 are not unusual within the territory of the present-day Turkey. Over the course of the past century, several tens of them have been observed [13]. Sometimes the Istanbul environs are affected by powerful earthquakes. A number of significant earthquakes were reported by some historians, and there is also evidence from geological investigations available invoked in favor thereof. 


\section{Информатика и вычислительная техника}

Our map of the equipotential distribution of the geodynamic risk probability indexing, covering the neighborhood area of Istanbul, with the plotted epicenters of the earthquakes of magnitudes 3,8 to 5,2 which occurred in the period 1999-2008, is given below (Fig. 5) [14].

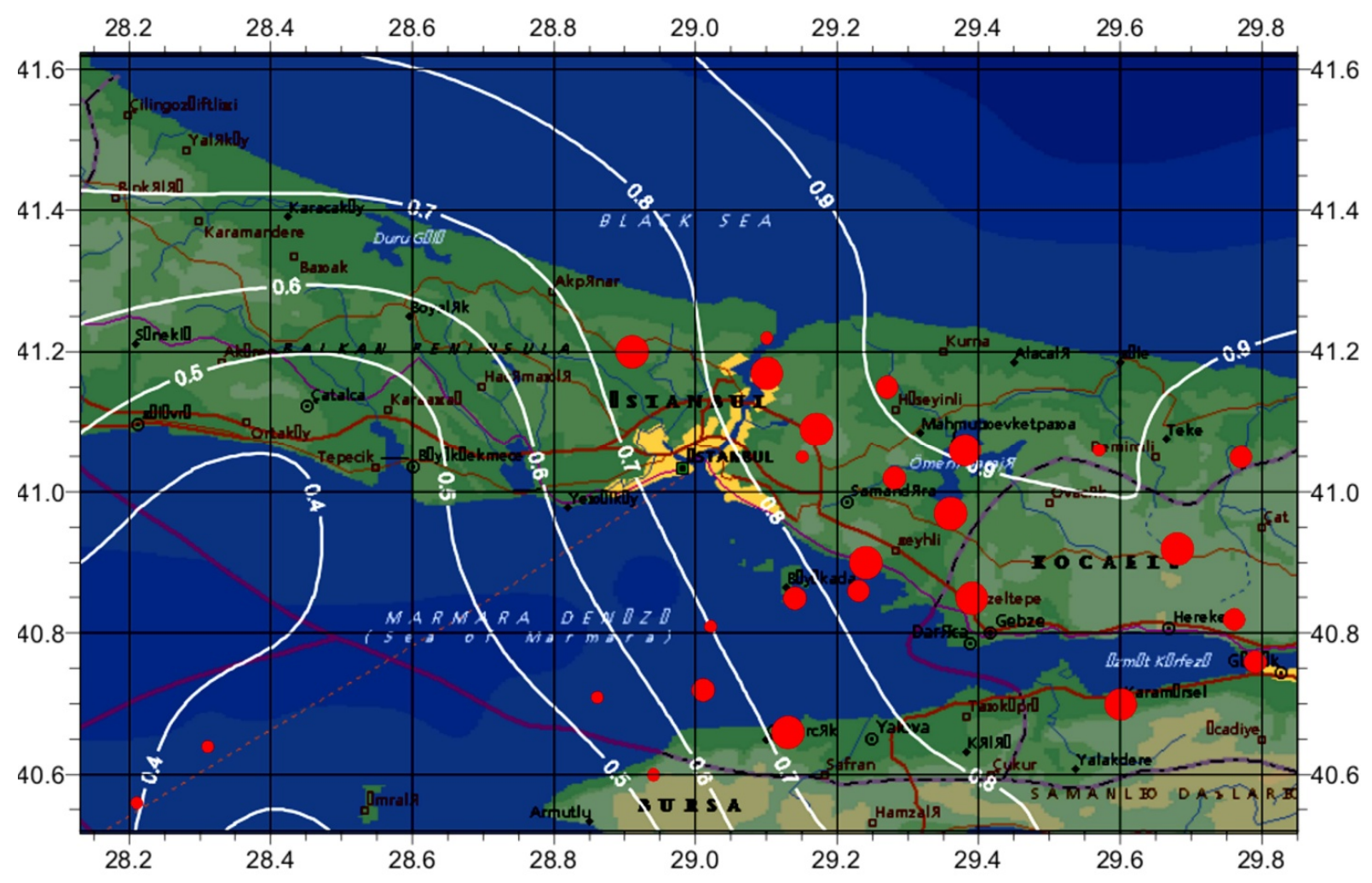

Fig. 5. Assessment map of equipotential distribution of geodynamic risk probability index numbers for the neighborhood area of Istanbul with the plotted epicenters of the actual earthquakes of magnitudes 3,8 to 5,2 , which occurred in the period 1999-2008

We are of the opinion that the regions, contoured with the 0,4 index probability isolines, should be considered as latent-potential risk zones, the 0,5 index isoline marked regions should be treated as moderate risk zones; the 0,7 index isoline regions should be high-risk zones, and the 0,8 index isoline locations should belong to extremely hazardous zones. The distribution of the epicenters of the actual earthquakes lends support to the adequacy of the geodynamic risk assessment procedure developed by the authors hereof.

The given map shows that the seismic events in the vicinity of Istanbul in the period 1999-2008 occurred in the districts north and east of the city, with the last earthquake dated the $28^{\text {th }}$ of October 2006. The latest seismic event took place on the $5^{\text {th }}$ of October 2008 on the southern coast of the Sea of Marmara. It indicates that the seismic activity focus migrates towards the south of Istanbul that is confirmed by the facts of the actual earthquakes of magnitude under 3, which occurred in the first decade in April 2010 (when we were preparing our calculations) [15].

Since this city is located in the high risk zone, with its part located even in the extremely hazardous area, it should be noted, that a reverse migration of the seismic activity focus might be expected to a site within the city of Istanbul. Due to the fact that the tectonic strains have been released in comparatively recent time there, that has been reflected in some insignificant earthquake events of small magnitudes, it is not likely that any big seismic events might be expected within the nearest future there. But the probability of the occurrence of some small-magnitude events (of magnitude under 4), in our opinion, is very high for the affected region. Should the predicted small-magnitude earthquakes not occur within the nearest time (in the 2-3 year period), then the risk of a big seismic event should be in run that might become a large-scale disaster for this city with several million population. 
Therefore, we think it is expedient to make more intense the instrumentation monitoring of the current vertical and horizontal movements within the affected area of the above mentioned city. In doing so, it is necessary to carry out in more detail further comprehensive investigations within the city territory in order to reveal most critical zones of high risk geodynamics.

\section{Conclusions}

Thus, the mathematical technology of the seismic risk assessment treated herein offers undoubtedly the advantage over other risk assessment methods, based solely on the analysis of the spatio-temporal rows of observational data, because the proposed technology makes possible to predict true the final results to control the safety of the population and the affected territories in case of the occurrence of hazardous processes of geodynamic origin, among them the earthquakes.

The special features of this technology are that, first, it is just the method of the mathematical modeling that plays a dominating role at the decision-making level in assessing the territories, and that, second, the approach, forming the basis of this technology, is a cost-effective one because no additional instrumentation surveys are required, and that, third, the method of the mathematical modeling grants us a freedom in choosing any object of the investigations.

The adequacy of the mathematical models developed by us on the basis of this technology is confirmed more than once by the computations and the correlations between the obtained results and the distributions of the actual hazardous geodynamic events in various regions in Russia and abroad.

However, the foregoing is not meant to minimize by any means the importance of other existing methods utilized for seismic risk evaluation, provided that they are capable of delivering plausible results. For instance, now we are developing new mathematical models aimed at revealing a structure of the displacement field in the geo-environment, the data on which in combination with the space geodesy data, supplemented by those from the monitoring seismic networks will allow us coming close to the solution of the problem how to predict significant energy class earthquakes and prevent their catastrophic consequences.

In conclusion, we should note the following.

The problem of the seismic risk assessment knows no national borders. So, in evaluating the seismic risk for any country in the world, we are bound to assess the relevant seismic risks for territories of the neighboring countries, whatever their will may be [16]. But if the concerned country requires such risk assessment technique, so it is necessary to supply additional data on the geological environment, as mentioned above, in order to assess the risks more exactly. That is to say that requires developing of international cooperation in researches and collaboration between experts and scientists in a great diversity of scientific fields. It should also include joint surveys of the seismic activity of the Earth from Space. It should be stated in this connection, that an investment for such space exploration will return a hundredfold because enormous material and personal losses from unexpected or unpredicted seismic disasters may be avoided.

Unfortunately, an exact forecasting of earthquakes, among them seismic disaster cases, remains a present-day enigma, since so far all attempts to place the dynamics of hazardous natural phenomena in "the procrustean bed" of mathematics have failed. Nevertheless, the authors of this paper have every reason to believe that their further research and development work in the field of investigations of hazardous geodynamic phenomena will allow coming very close to the solution of this urgent issue that challenges all the mankind today.

In our view, the only way to provide the high-rate plausibility in identififying the critical geodynamic zones is to combine all geological, geophysical, geomorphological, mathematical and medical \& biological methods in researches within the framework of international cooperation of the scientists and experts throughout the world.

\section{References}

1. Ananyin I.V., Faddeev A.O. [Numerical Modeling of Strain State of Tectonic Disturbances of the Earth's Crust in Central Part of Eastern-European Platform (by example of the Moscow-RyazanSaratov Avlacogen)]. Materialyi Mezhdunarodnoy konferentsii "Geodinamika i geoekologiya" 


\section{Информатика и вычислительная техника}

[Internat. Math. Conf. "Geodynamics and Geo-Ecology”]. Arkhangelsk, Inst. for Environmental Problems of the North UrD RASc, 1999, pp. 11-14. (in Russ.)

2. Ananyin I.V., Faddeev A.O., Sim L.A. [Tectonic Stresses in the Earth's Crust in Central Part of Eastern-European Platform (Upon Results of Mathematical Modeling and Structural \& Geomorphological Data)]. Issues of Seismicity of Eastern-European Platform, 2000, pp. 3-18. (in Russ.)

3. Maslov I.A., Faddeev A.O. Physical and Mathematical Modeling of Geodynamics Processes. Physics of Vibration, 2002, vol. 10, no. 2, pp. 100-115.

4. Maslov I.A., Faddeev A.O. Analysis of Electric Activity Sources in Earthquake Area. Physics of Wave Phenomena, 2003, vol. 11, no. 3, pp. 168-175.

5. Faddeev A.O. [Geo-Ecological Risk in Residential and Industrial Areas]. Dual-Application Technologies, 2009, no.1, pp. 22-30. (in Russ.)

6. Minaev V.A., Faddeev A.O. [Modeling of Geo-Ecological Risks and Assessment of GeoEcological Safety in Recreational Areas]. Problems of Risk Management in Technosphere, 2008, no. 4, pp. 55-62. (in Russ.)

7. Faddeev A.O. [Model of Assessment of Regional Geo-Ecological Risk]. Issues of Safety and Emergency Cases, 2009, No.1, pp. 43-52. (in Russ.)

8. Minaev V.A., Faddeev A.O. [Geo-Ecological Risk Modeling]. Special Technical Facilities \& Communication, 2009, no. 2, pp. 24-30. (in Russ.)

9. Minaev V.A., Faddeev A.O. Otsenka geoekologicheskikh riskov: modelirovanie bezopasnosti turistsko-rekreatsionnykh territoriy [Geo-Ecological Risk Assessment. Modeling of Safety of Tourist \& Recreational Areas]. Moscow, Finance and Statistics, Publish. House INFRA-M, 2009. 370 p.

10. Minaev V.A., Faddeev A.O., Danilov R.M. [Mathematical Modeling of Risks of Geodynamic Origin]. Special Technical Facilities \& Communication, 2011, no.1, pp. 48-52. (in Russ.)

11. Minaev V.A., Faddeev A.O. [Probability Model for Seismic Risk Assessment // Bulletin of Russian New University]. Management, Computer Science and Informatics: Collection of Scientific Works, 2009, no. 2, pp. 15-24. (in Russ.)

12. Minaev V.A., Faddeev A.O. [Geo-Ecological Risks in Recreational Zones in the Baikal Region]. World \& Safety, no. 3, 2007, pp. 35-42. (in Russ.)

13. Katalog zemletryaseniy $v$ Turtsii v period 1913-1970 gg. Mirovoy tsentr dannykh po fizike tverdoy Zemli, Moskva [Catalog of Earthquakes in Turkey in the Period 1913-1970. Source: The World Data Center for Solid-Earth Physics, Moscow]. Available at: www.wdcb.ru.

14. Operativnyy seysmologicheskiy katalog Geofizicheskoy sluzhby RAN, Obninsk. Mirovoy tsentr dannykh po fizike tverdoy Zemli, Moskva [Current Seismological Catalog of the Geophysical Service at RASc, Obninsk. Source: The World Data Center for Solid-Earth Physics, Moscow]. Available at: www.wdcb.ru.

15. Dannyie Evropeyskogo Sredizemnomorskogo seysmologicheskogo tsentra. Mirovoy tsentr dannykh po fizike tverdoy Zemli, Moskva [Data from European-Mediterranean Seismological Center. Source: The World Data Center for Solid-Earth Physics, Moscow]. Available at: www.wdcb.ru.

16. Minaev V.A., Faddeev A.O., Abramova A.V., Pavlova S. A. [Mathematical Modeling of Seismic Risks]. Special Technical Facilities \& Communication, 2013, no 5, pp. 58-63. (in Russ.)

Received 25 December 2017 


\title{
МАТЕМАТИЧЕСКАЯ МОДЕЛЬ ГЕОДИНАМИЧЕСКОЙ ОЦЕНКИ РИСКОВ
}

\author{
В.Н. Бурков ${ }^{1}$, И.В. Буркова ${ }^{1,2}$, В.А. Минаев ${ }^{3}$, А.О. Фаддеев ${ }^{4}$ \\ ${ }^{1}$ Институт проблем управления им. В.А. Трапезникова РАН, г. Москва, Россия, \\ ${ }^{2}$ Российский государственный гуманитарный университет, г. Москва, Россия, \\ ${ }^{3}$ Московский государственный технический университет им. Н.Э. Баумана, \\ г. Москва, Россия, \\ ${ }^{4}$ Академия Федеральной службы исполнения наказаний России, е. Рязань, Россия
}

\begin{abstract}
Представлена математическая модель оценки геодинамических катастроф, в частности землетрясений, основанная на анализе косвенных показателей геодинамической неустойчивости, а именно - горизонтальных градиентов гравитационных аномалий в изостатической редукции. Особое внимание уделяется вероятностной математической модели оценки сейсмических рисков, суть которой заключается в представлении возможных геодинамических состояний геологической среды, связанных простейшими потоками событий, описываемых системой дифференциальных уравнений Колмогорова. Приведены основные результаты практического применения математических моделей, разработанных авторами, для оценки сейсмических рисков, на примерах Байкальского региона и северо-западной территории Турции.

Ключевые слова: математическое моделирование, геодинамический риск, гравитационные аномалии, геодинамические опасности, напряжения и смещения, геологическая среда, землетрясения.
\end{abstract}

\section{Литература}

1. Ананьин, И.В. Численное моделирование напряженного состояния тектонических нарушений в земной коре Центральной части Восточно-Европейской платформы (на примере Московско-Рязано-Саратовского авлакогена) / И.В. Ананьин, А.О. Фаддеев // Материаль Международной конференции «Геодинамика и геоэкология». - Архангельск: Институт экологических проблем Севера УрО РАН, 1999. - С. 11-14.

2. Ананьин, И.В. Тектонические напряжения в земной коре центральной части ВосточноЕвропейской платформы (по результатам математического моделирования и структурногеоморфологическим данным) / И.В. Ананьин, А.О. Фаддеев, Л.А. Сим // Проблемы сейсмичности Восточно-Европейской платформы: сб. - М.: Изд-во ОИФЗ РАН, 2000. - С. 3-18.

3. Maslov, I.A. Physical and Mathematical Modeling of Geodynamics Processes / I.A. Maslov, A.O. Faddeev // Physics of Vibration. - 2002. - Vol. 10, no. 2. - P. 100-115.

4. Maslov I.A., Faddeev A.O. Analysis of Electric Activity Sources in Earthquake Area / I.A. Maslov, A.O. Faddeev // Physics of Wave Phenomena. - 2003. - Vol. 11, no.3. - P. 168-175.

5. Фаддеев, А.О. Геоэкологический риск на заселенных и промышленных территориях / А.О. Фаддеев // Двойные технологии. - 2009. - № 1. - С. 22-30.

6. Минаев, В.А. Моделирование геоэкологических рисков и оценка геоэкологической безопасности на рекреационных территориях / В.А. Минаев, А.О. Фаддеев // Проблемы управления рисками в техносфере. - 2008. - № 4. - С. 55-62.

7. Фаддеев, А.О. Модель оценки регионального геоэкологического риска / А.О. Фаддеев // Проблемы безопасности и чрезвычайных ситуаций. - 2009. - № 1. - C. 43-52.

8. Минаев, В.А. Моделирование геоэкологического риска / В.А. Минаев, А.О. Фаддеев // Спеитехника и связь. - 2009. - № 2. - С. 24-30.

9. Минаев В.А., Фаддеев А.О. Оиенка геоэкологических рисков: моделирование безопасности туристско-рекреационных территорий. М.: Финансы и статистика; ИНФРА-М, 2009. - 336 с.

10. Минаев, В.А. Математическое моделирование рисков геодинамического происхождения / В.А. Минаев, А.О. Фаддеев, Р.М. Данилов // Спецтехника и связь. - 2011. - № 1. - С. 48-52. 


\section{Информатика и вычислительная техника}

11. Минаев, В.А. Вероятностная модель оиенки сейсмических рисков / В.А. Минаев, А.О. Фаддеев // Вестник Российского нового университета. Серия «Сложные системы: модели, анализ, управление». - М.: Российский новый университет, 2009. - № 2. - С. 15-24.

12. Минаев, В.А. Геоэкологические риски рекреаџионных зон Байкальского региона / В.А. Минаев, А.О. Фаддеев // Мир и безопасность. - № 3. - 2007. - С. 35-42.

13. Каталог землетрясений в Туричи в период 1913-1070 г2. // Мировой иентр данных по физике твердой Земли, Москва. - www.wdcb.ru.

14. Оперативный сейсмологический каталог Геофизической службы РАН, Обнинск // Мировой иентр данных по физике твердой Земли, Москва. - www.wdcb.ru.

15. Данные Европейского Средиземноморского сейсмологического иентра // Мировой иентр данных по физике твердой Земли, Москва. - www.wdcb.ru.

16. Математическое моделирование сейсмических рисков / В.А. Минаев, А.О. Фаддеев, А.В. Абрамова, С.А. Павлова // Спецттехника и связь. - 2013. - № 5. - С. 58-63.

Бурков Владимир Николаевич, д-р техн. наук, профессор, заведующий лабораторией активных систем, Институт проблем управления им. В.А. Трапезникова РАН, г. Москва, Россия; vlab17@bk.ru.

Буркова Ирина Владимировна, д-р техн. наук, доцент, профессор кафедры моделирования в экономике и управлении, Российский государственный гуманитарный университет; ведущий научный сотрудник лаборатории активных систем, Институт проблем управления им. В.А. Трапезникова РАН, г. Москва; irbur27@mail.ru.

Минаев Владимир Александрович, д-р техн. наук, профессор, профессор, Московский государственный технический университет им. Н.Э. Баумана, г. Москва; m1va@yandex.ru.

Фаддеев Александр Олегович, д-р техн. наук, доцент, профессор, Академия Федеральной службы исполнения наказаний России, г. Рязань; fao1@mail.ru.

Поступила в редакцию 25 декабря 20172.

\section{ОБРАЗЕЦ ЦИТИРОВАНИЯ}

Mathematical Model of Geodinamic Risk Assessment / V.N. Burkov, I.V. Burkova, V.A. Minaev, A.O. Faddeev // Вестник ЮУрГУ. Серия «Компьютерные технологии, управление, радиоэлектроника». - 2018. T. 18, № 1. - C. 37-46. DOI: $10.14529 /$ ctcr180104

\section{FOR CITATION}

Burkov V.N., Burkova I.V., Minaev V.A., Faddeev A.O. Mathematical Model of Geodinamic Risk Assessment. Bulletin of the South Ural State University. Ser. Computer Technologies, Automatic Control, Radio Electronics, 2018, vol. 18, no. 1, pp. 37-46. DOI: 10.14529/ctcr180104 